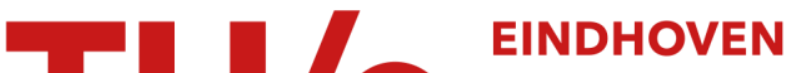

\section{First demonstration of HD video distribution over large-core POF employing UWB for in-home networks}

\section{Citation for published version (APA):}

Shi, Y., Visani, D., Okonkwo, C. M., Yang, H., Van Den Boom, H. P. A., Tartarini, G., Tangdiongga, E., \& Koonen, A. M. J. (2011). First demonstration of HD video distribution over large-core POF employing UWB for in-home networks. In Proceedings of the Optical Fiber Communication Conference (OFC), 6-10 March 2011, Los Angeles, California (pp. OWB5-1/3). [5875645]

\section{Document status and date:}

Published: 11/07/2011

\section{Document Version:}

Accepted manuscript including changes made at the peer-review stage

\section{Please check the document version of this publication:}

- A submitted manuscript is the version of the article upon submission and before peer-review. There can be important differences between the submitted version and the official published version of record. People interested in the research are advised to contact the author for the final version of the publication, or visit the $\mathrm{DOI}$ to the publisher's website.

- The final author version and the galley proof are versions of the publication after peer review.

- The final published version features the final layout of the paper including the volume, issue and page numbers.

Link to publication

\section{General rights}

Copyright and moral rights for the publications made accessible in the public portal are retained by the authors and/or other copyright owners and it is a condition of accessing publications that users recognise and abide by the legal requirements associated with these rights.

- Users may download and print one copy of any publication from the public portal for the purpose of private study or research.

- You may not further distribute the material or use it for any profit-making activity or commercial gain

- You may freely distribute the URL identifying the publication in the public portal.

If the publication is distributed under the terms of Article $25 \mathrm{fa}$ of the Dutch Copyright Act, indicated by the "Taverne" license above, please follow below link for the End User Agreement:

www.tue.nl/taverne

Take down policy

If you believe that this document breaches copyright please contact us at:

openaccess@tue.nl

providing details and we will investigate your claim. 


\section{IEEEXplore}




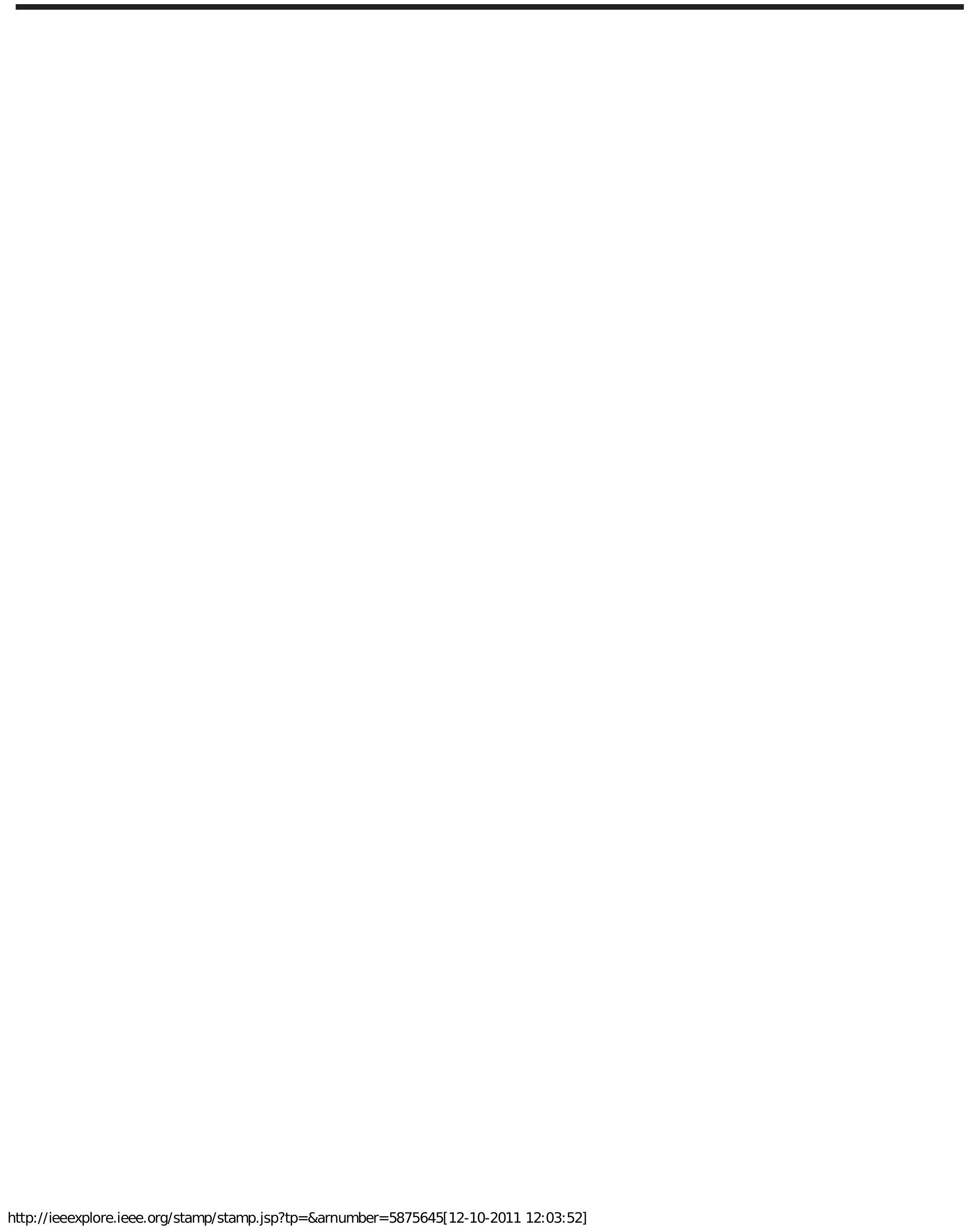

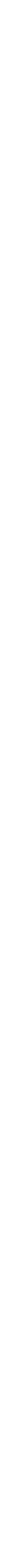

